\title{
ADDING DERIVATIVES TO THE CORPORATE LAW MIX
}

\author{
Frank Partnoy" \\ It is still an unending source of surprise for me to \\ see how a few scribbles on a blackboard or on a \\ sheet of paper could change the course of human \\ affairs.
}

Stanislaw Ulam ${ }^{1}$

\section{INTRODUCTION}

In less than three decades, financial derivatives ${ }^{2}$ have changed the world. The story is remarkable: in 1973, a few economists discover a differential equation that models the pricing of contingent claims, including options. ${ }^{3}$ Soon thereafter, market participants begin using versions of the equation to value their transactions. New methodologies evolve, and options and futures exchanges develop and flourish. Over-the-counter derivatives, including swaps, ${ }^{4}$ quickly become a trillion-dollar market.

- Associate Professor of Law, University of San Diego School of Law; J.D. 1992, Yale Law School. I am grateful to Shaun Martin, Tom Smith, and Chris Wonnell for comments and to Jeff Carroll for research assistance.

1 RICHARD RFODES, THE MAKING OF THE ATOMIC BOMB 11 (1986).

2 Financial derivatives generally are described as instruments whose value is "derived" from some other underlying financial instrument or index. For a more detailed description of these instruments see Part II.

3 For an explanation of this model see Fisher Black \& Myron S. Scholes, The Pricing of Options and Corporate Liabilities, 81 J. POL. ECON. 637 (1973). This equation, known as the Black-Scholes equation or model, states that the price of an option on a stock depends on six variables: the price of the stock, the exercise price, the time to expiration of the option, the risk-free interest rate during that period, the dividend yield on the stock, and an applicable measure of volatility.

- Swaps-including interest-rate swaps, currency swaps, and more exotica-are simply agreements between counter-parties to exchange cash flows during some period of time, based on one or more underlying indices or instruments. 
By the 1990s, financial innovation had worked a "revolution,"5 making the concepts of "stocks" and "bonds" as quaint and obsolete as the discovery of fundamental particles made the elements of earth, air, fire, and water. Today, the derivatives market is by far the largest market in the world, financial or otherwise, and it continues to grow. ${ }^{6}$

Meanwhile, corporate law has been left in the dust. For the study and practice of corporate law, the consequences of the derivatives revolution are devastating. Many of the traditional building blocks no longer exist. Some basic corporate law concepts, including the notion that managers should owe fiduciary duties to shareholders, rest on a shaky foundation at best. Core cases are peppered with references to complex financial instruments and options transactions. ${ }^{7}$

Today, a practicing lawyer unaware of how derivatives may be used to create new risk-return profiles, add leverage, or satisfy regulatory requirements hardly has a chance of surviving even a cocktail party with sophisticated clients. This fact is true not only for corporate lawyers, who must understand pricing techniques in some detail (e.g., to evaluate disclosure of options valuation), but also for litigators, who must understand how complex derivatives are sold (e.g., to understand lawsuits by purchasers of such instruments), and for lawyers-turned-business people, who must understand numerous advances in modern finance (e.g., to assess treasury functions, including compensation).

5 See MERTON H. MILler, MERTON MLLLeR ON DERIVATIVES 3 (1997) (describing recent major changes in finance during the 1990s as derivatives "revolution"). Certain types of simple derivatives have existed for centuries; the "revolution" involves more complex instruments as well as advances in the ability to value contingent claims more precisely.

6 Recent estimates of the size of the market for financial derivatives are in the range of $\$ 80$ trillion, many times the market capitalization of the United States equity markets. See Alan Greenspan, Address to the Futures Industry Association (Mar. 19, 1999) (citing estimates of derivatives' exposing growth). Some commentators have noted that this comparison is like comparing apples to oranges. The $\$ 80$ trillion figure is simply the "notional amount" of the instruments underlying derivative transactions, and the actual amounts at risk are perhaps only a fraction of that value. However, the entire value of the United States equity market cannot reasonably be said to be at risk, and events such as the near-collapse of Long-Term Capital Management in 1998 have raised questions about whether at-risk exposure for derivatives may be larger than anticipated. In any event, the debate is one of degree; no one doubts that the derivatives market is large.

7 I describe some examples of such cases in Part IV. 
For scholars, arguments about derivatives have generated some of the most interesting conceptual and analytical problems in corporate law. ${ }^{8}$ Derivatives have sparked heated public debate about policies related to financial market regulation, with arguments ranging from financier George Soros's warning that derivatives traders cause instability that will "destroy society" to economist Merton Miller's defense that derivatives "have made the world a safer place."10

At the same time, derivatives have generated great drama. They have made some people, including a few lawyers, astonishingly rich. ${ }^{11}$ They have bankrupted or decimated numerous institutions,

8 These problems relate both to how derivatives are used and, more fundamentally, to how derivatives affect the theory of the firm. Legal academics have noted problems related to the three uses of derivatives: hedging, speculating, and arbitrage (including regulatory arbitrage). See, e.g., Kimberly D. Krawiec, Derivatives, Corporate Hedging, and Shareholder Wealth: Modigliani-Miller Forty Years Later, 1998 U. ILL. L. REV. 1039 (noting hedging problem); Frank Partnoy, Financial Derivatives and the Costs of Regulatory Arbitrage, $22 \mathrm{~J}$. CoRP. L. 211 (1997) (noting arbitrage problem); Lynn A. Stout, Betting the Bank: How Derivatives Trading Under Conditions of Uncertainty Can Increase Risks and Erode Returns in Financial Markets, 21 J. CORP. L. 53 (1995) (noting speculating problem).

9 See Frank P.artnoy, Playing Roulette with the Global Economy, N.Y. TmES, Sept. 30, 1998, at A17 (quoting Soros).

10 MilleR, supra note 5 , at ix.

11 Derivatives salespeople and traders are paid as much as professional athletes and movie stars. Although derivatives lawyers typically are paid much less, a few have received multi-million-dollar fees from lawsuits related to sales of derivatives. See Bruce W. Whitaker, Orange County Voices; A "Trick" on County, A "Treat" for Lawyers, L.A. TIMES, Oct. 31, 1999, at B19 (citing law firm of Hennigan, Mercer \& Bennett's pursuit of $\$ 48.7$ million in fees, following $\$ 26.3$ million in fees already collected by firm, for its representation of Orange County in suits related to derivatives losses). Ironically, some derivatives participants have criticized claims about large bonuses paid to derivatives employees as vastly understating the money being made. See, e.g., That \#\%@! Book, DERIVATIVES STRATEGY, Nov. 1997, at 13 ("What he thinks of as a lot of money isn't a lot of money. He thinks that people who are worth $\$ 50$ million are rich guys. In this world, lots of people have that kind of money. Nobody's impressed when they hear you have guys at the firm making \$6 million. Hedge funds pay administrators that much just to keep track of their positions."). These salaries are due in part to the large markups charged on derivatives transactions. Well-known hedge fund manager Victor Niederhoffer has supplied evidence of such markups, claiming he was sophisticated enough to calculate these large profits margins (ranging to one hundred percent) embedded in derivatives transactions. Niederhoffer even warned dealers about such fees, "Please don't put that in writing. If my customers found out I considered such a quote, they would have you and me locked up." VICTOR NIEDERHOFFER, THE EDUCATION OF A SPECULATOR 177 (1997). Niederhoffer's story is a fascinating one. After fifteen years of thirty percent-plus returns, Niederhoffer's fund lost about $\$ 50$ million (about half of its value) following the devaluation of the Thai baht in July 1997. In October 1997, in a desperate attempt to avoid a losing year, he sold large amounts of Standard \& Poor's 500 put options, 
and recent financial crises invariably have involved derivatives. ${ }^{12}$ Derivatives have come to possess a mystique, captured not only in front-page news headlines, but increasingly in fiction too. ${ }^{13}$

Of course, I will not attempt to argue here that the complex mathematics of financial derivatives resemble drama, or even that they bear mention in the basic corporate law course (or, perhaps, in law school at all). ${ }^{14}$ The models used to price derivatives are based on the random behavior of financial assets and employ stochastic calculus and partial differential equations. They are not easy. ${ }^{15}$ Fortunately, they are not necessary, either. ${ }^{16}$ Most individuals in the derivatives industry are not "rocket scientists" and legal academics, practitioners, and students-even those who cannot balance a checkbook-should be able to understand the basic principles of derivatives without rigorous mathematical treatment. ${ }^{17}$

betting that the market would not go down; when the United States stock market fell seven percent on Monday, October 27, 1997, Niederhoffer's $\$ 100$ million-plus fund was bankrupted. FRANK PARTNOY, F.I.A.S.C.O.: BLOOD IN THE WATER ON WALL STREET 259-61 (1999).

12 Notable examples include billions of dollars of losses from derivatives incurred by Barings Bank, Daiwa Bank, Long-Term Capital Management, Orange County, Procter \& Gamble, Sumitomo Corporation, and Yakult Honsha; derivatives also played a prominent role in the Asia crisis of 1997. E.g., ChARLES ADAMS ET AL., INTERNATIONAL CAPITAL MARKETS: DEVELOPMENTS, PROSPECTS, AND KEY POLICY ISSUES 40-55, 97-103 (1998).

${ }_{13}$ See, e.g., STEPHEN RHODES, THE VELOCITY OFMONEY: ANOVELOF WALLSTREET (1997) (describing derivatives); Frank Partnoy, High-Finance Fiction, L.A. TiMES, Feb. 8, 1998, at 16-17 (book review) (describing use of financial innovation in recent literature).

14 Some of these concepts, including a version of the Black-Scholes equation (although not its derivation), belong in more advanced law school courses, especially in Corporate Finance. It is worth noting that in response to student demand and professor interest, law schools are beginning to offer seminars in derivatives, although I am not aware of any course that includes a rigorous treatment of derivatives pricing and valuation.

15 See generally JOHN C. HULL, OPTIONS, FUTURES, AND OTHER DERIVATIVE SECURITIES (1989) (describing financial derivative calculation); ROBERT C. MERTON, CONTINUOUS-TIME FINANCE (1998) (describing same); SALIH N. NEFTCI, AN INTRODUCTION TO THE MATHEMATICS OF FinaNCIAL DERIVATIVES (1996) (describing same); PAUL WILMOTT, DERIVATIVES: THE THEORY AND PRACTICE OF FINANCIAL ENGINEERING (1998) (describing same); THE HANDBOOK OF DERIVATIVE INSTRUMENTS: INVESTMENT RESEARCH, ANALYSIS AND PORTFOLIO APPLICATIONS (Atsuo Konishi \& Ravi E. Dattatreya eds., 1991) (describing same).

16 Law students and scholars need not be conversant in such topics as geometric Brownian motion, Wiener processes, and Ito's lemma.

17 The intuition behind most derivative instruments can be expressed without complex mathematics. The size of the derivatives market supports this belief. Otherwise, how could so many derivatives be traded? Managers of mutual and pension funds, corporate and government treasury departments, and insurance companies all buy derivatives without understanding many of the details about the mathematics of pricing. Moreover, courts generally have held that a purchaser of derivatives need not understand the highest level of 
For scholars who are not persuaded by the above points, I offer one last exhortation: you do not have a choice. Anyone teaching corporate law inevitably confronts derivatives in some form. ${ }^{18}$ Options especially play a central role in modern cases, and increasingly in practice. How can anyone teach United States v. O'Hagan, ${ }^{19}$ Smith v. Van Gorkom, ${ }^{20}$ or Revlon, Inc. v. MacAndrews \& Forbes Holdings, Inc. ${ }^{21}$ without mentioning options? The trend is clear: in the future, derivatives undoubtedly will invade corporate law in ways no one can anticipate. This Essay, therefore, is intended merely as a starting point for professors interested in adding derivatives to the mix of their basic corporate law course.

In Part II, ${ }^{22}$ I describe the basic classes and uses of derivatives. In Part III, ${ }^{23}$ I analyze how derivatives challenge current approaches to the nature of the firm and fiduciary duty. In Part IV, ${ }^{24} \mathrm{I}$ focus on how evaluation of derivatives, especially options, can contribute to an understanding of particular cases already taught in the basic

complexity, and caurts have dismissed claims by investors alleging sellers of derivatives engage in fraud when they fail to ensure such understanding. See, e.g., Societe Nationale D'Expoitation Industrielle Des Tabacs et Allumettes v. Salomon Bros., No. 113154/96, 1998 N.Y. Misc. LEXIS 219 (Feb. 9, 1998) (granting summary judgment for defendants where plaintiff sought to recover damages caused by failure to understand complex swap transaction). Even the Black-Scholes formula should not be inaccessible. Under certain limited conditions ifor short-dated options when the underlying stock price equals the present value of the exercise price), an approximation is quite simple: the value of the option as a fraction of the price of the stock is simply 0.4 multiplied by the volatility of the stock multiplied by the square root of the time to maturity (expressed as a fraction of a year). For example, if the risk-free interest rate is eight percent, the stock price is $\$ 100$, the exercise price is $\$ 108.33$, the volatility is twenty percent, and the time to expiration is one year, a call option with an exercise price of $\$ 108.33$ should be worth approximately $\$ 100 \times 0.4 \times 0.2 \times 1$ $=\$ 8$, roughly the value generated by the full-blown version of the Black-Scholes model.

is Every corporate law text includes some cases and materials about derivatives. E.g., ChaRles R.T. O'KELleY \& ROBERT B. THOMPSON, CORPORATIONS AND OTHER BuSINESS ASSOCIATIONS: CASESAND MATERIALS 1212-13 (3d ed. 1999). Indeed, just as a hundred years ago, many law school courses could have been taught using exclusively railroad cases, today corporate law could be taught using only derivatives-related materials.

19521 U.S. 642 (1997) (reinstating conviction of attorney in insider trading scheme involving call options on Pillsbury stock).

20488 A.2d 858, 877 (Del. 1985) (involving call option on Trans Union stock).

21506 A.2d 173 (Del. 1985) (involving lock-up option on Revlon stock).

22 See infra nctes 26-35 and accompanying text.

${ }^{23}$ See infra nctes $36-52$ and accompanying text.

24 See infra nctes 53-92 and accompanying text. 
course. In Part V, ${ }^{25}$ I suggest additional ideas for how derivatives might be used in the basic course.

\section{Classes AND Uses of DeRIVATIVES}

There are two basic classes of derivatives: options and forwards. Options are more important than forwards in corporate law, and, therefore, deserve a more detailed explanation here. Options are the right to buy (a call option) or sell (a put option) an instrument or index at a specified time (the exercise date) and price (the exercise price). ${ }^{26}$ There are two sides to every options contract: the "Iong" position buys the option; the "short" position sells it.

For example, suppose Qualcomm, Inc., has stock valued at $\$ 100$ per share. Qualcomm also has options with various exercise prices and dates. Suppose there is a market for one-month Qualcomm call and put options with an exercise price of $\$ 100 .^{27}$ Assume each of these options costs $\$ 5$ (the premium).

There are four possible positions in Qualcomm options: long call, short call, long put, and short put. Each of these positions has a very different payoff profile. Each of the long positions must pay the $\$ 5$ premium up front. In contrast, each of the short positions receives the $\$ 5$ premium up front. The long positions will not lose any more than $\$ 5$ and could make much more. The short positions cannot gain any more than $\$ 5$ and could lose much more.

First, consider the call option. The long call makes money (and the short call loses an equivalent amount) when the stock price increases. ${ }^{28}$ If Qualcomm stock is worth $\$ 150$ in one month, the long

25 See infra text following note 92.

26 This price also is referred to as the "strike" price. FranK J. FABOZZI, THE HANDBOOK OF FIXED INCOME SECURITIES 1081 (4th ed. 1995).

${ }^{27}$ Such an option is referred to as "at-the-money" because the exercise price equals the current price of the underlying stock. An option that, if exercised, would have positive value today is referred to as "in-the-money"; an option that, if exercised, would have negative value today is referred to as "out-of-the-money." For example, a call option on Qualcomm stock with an exercise price of $\$ 90$ would be in-the-money; a call with an exercise price of $\$ 110$ would be out-of-the-money.

28 This result is because the holder of a call option has the right to buy stock for less than the market price. The holder could exercise the option and sell the stock, to capture the difference between the market price and the exercise price. Alternatively, the holder could simply sell the option. 
call will have gained $\$ 50$ (for a $\$ 45$ net gain, including payment of the premium $)^{29}$ and the short call will have lost the same amount, $\$ 50$ (for a $\$ 45$ net loss, including receipt of the premium). If Qualcomm stock is worth only $\$ 50$ in one month, the long call will not exercise the option and thus will have gained nothing (for a net loss of \$5) and the short call will have lost nothing (for a net gain of $\$ 5) .^{30}$

Second, consider the put option. The long put makes money (and the short put loses an equivalent amount) when the stock price decreases. ${ }^{31}$ If $Q$ ualcomm stock is worth $\$ 50$ in one month, the long put will have gained $\$ 50$ (for a $\$ 45$ net gain, including payment of premium) and the short put will have lost the same amount, $\$ 50$ (for a $\$ 45$ net loss, including receipt of premium). If Qualcomm stock is worth $\$ 150$ in one month, the long put will let the option expire and thus will have gained nothing (for a net loss of \$5) and the short put will have lost nothing (for a net gain of \$5). ${ }^{32}$ Graphically, the payoffs at maturity to the various option holders are depicted in Figure 1.

29 This simplified example does not account for the time value of money; it assumes interest rates are zero.

${ }^{30}$ If the price of the stock on the expiration date is less than the exercise price, the call option is said to "expire worthless." Because a long call option loses $\$ 5$ for stock prices less than the exercise price, and makes increasing amounts (on a dollar-for-dollar basis) for stock prices greater than the exercise price, the payoff of a long call option position-like that of all option positions-is said to be "asymmetric."

31 This is because the owner of a put option has the right to sell stock for more than the market price.

32 Similarly, if the price of the stock on the expiration date is greater than the exercise price, the put option is said to "expire worthless." 
Figure 1

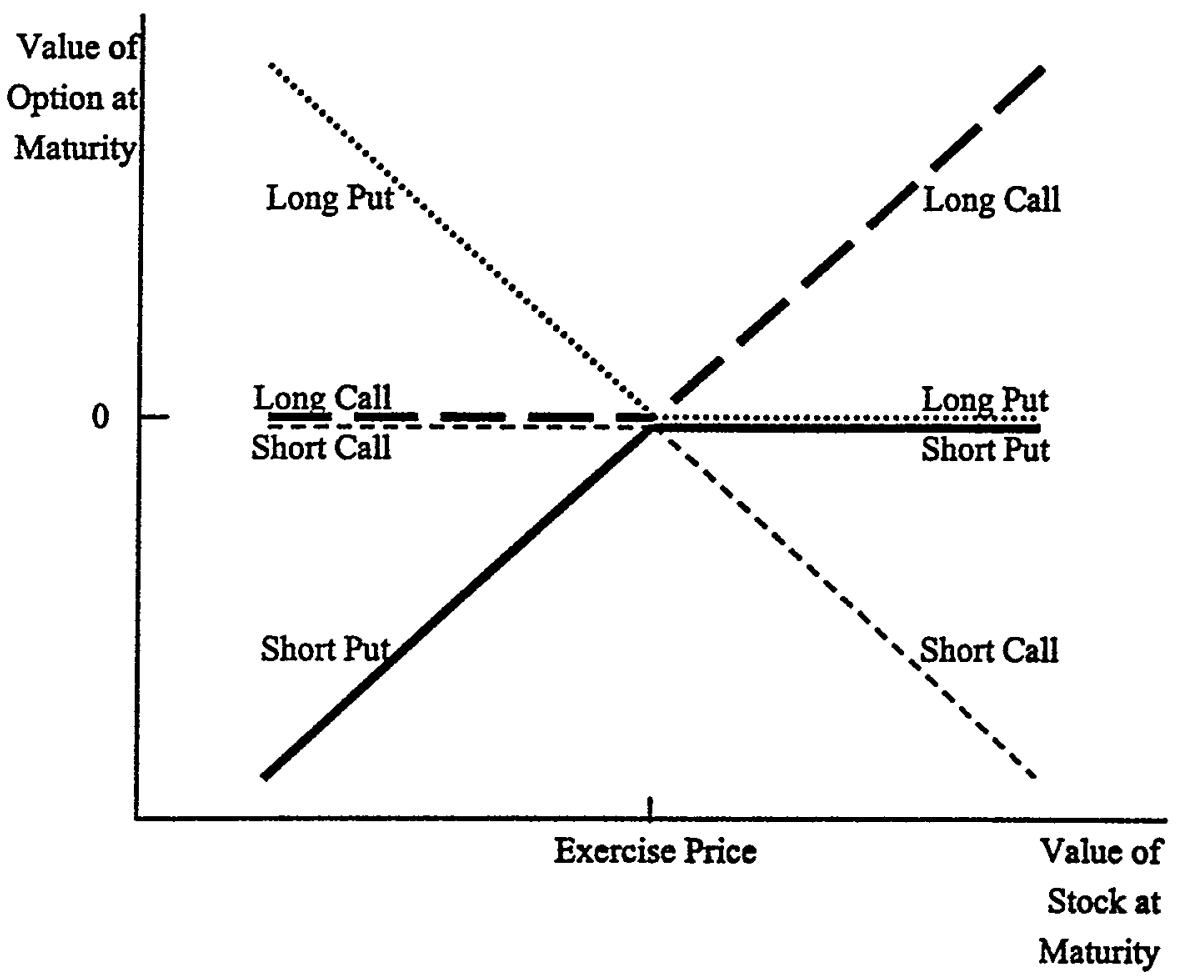

Note that the option payoffs are mirror images. The "legs" of the " $X$ " in Figure 1 are reflections of each other. This mirror-like aspect $t^{33}$ of options is no coincidence. The long call payoff exactly offsets the short call payoff; likewise, the long put payoff exactly offsets the short put payoff. Similarly, the long call gain for a given price increase exactly matches the long put gain for a price decrease of equal magnitude; likewise, the short call loss for a given price increase exactly matches the long put loss for a price decrease of equal magnitude.

s3 Students seem to grasp the simplicity of the mirror image in Figure 1. In addition, I have found it useful to describe long calls and short puts as "rooting" for the stock price to go up (or at least not to go down), and long puts and short calls as "rooting" for the stock price to go down (or at least not to go up), with the obligatory happy and sad faces as supplementary visual aids. 
Forwards are less important in corporate law, although they arise in numerous contexts. Whereas options are contractual rights, forwards are contractual rights and obligations. A forward is the right and obligation to buy or sell an instrument or index at a specified time and price. The party agreeing to buy the asset at some forward date has a "long" position; the party agreeing to sell the asset has a "short" position.

When parties enter into a forward contract, they typically set the forward price so that the initial value of the contract to both parties is zero. ${ }^{34}$ Then, prior to the maturity of the contract, if the value of the underlying instrument increases, the long position makes money. The converse is likewise true. Thus, the value of the short position exactly offsets the value of the long position.

For example, suppose two parties enter into a forward contract on Qualcomm stock at a forward price of $\$ 100$. If the value of Qualcomm stock rises above $\$ 100$, the long position, which has agreed to buy Qualcomm for $\$ 100$, makes money. If the value falls below $\$ 100$, the short position makes money.

Options and forwards are the basic building blocks of all derivatives transactions, and they can be combined in all sorts of fantastic ways to create hybrid securities. ${ }^{35}$ For example, swaps are agreements between parties to exchange cash flows at specified times according to a prearranged formula, and therefore may be thought of as a series of forward contracts. Regardless of the complexity of a transaction, it typically can be split into combinations of various types of options and forwards. Because options have an asymmetric payoff, they can be thought of as insurance contracts. Because forwards have a symmetric payoff, they can be thought of as hedging contracts. In these terms, all derivatives can be thought of as combinations of insurance and hedging contracts.

One final point: all derivatives can be used in one or more of three ways: (1) hedging (to reduce risk), (2) speculating (to increase risk and, hopefully, return), and (3) arbitrage (to capture riskless

3 The forward price may be set so that one party owes the other some amount up front. For such contracts, the party owed money may insist on collateral to compensate for the risk of default. Similarly, collateral may be required during the lifetime of a forward contract.

${ }^{35}$ For a more detailed description, see Partnoy, supra note 8, at 216-27. 
profit). How a derivative is being used may not be clear based on the nature of the contract. For example, purchasers of call options may be hedging (a manufacturer insuring against an increase in the price of some input), speculating (a day trader gambling on an Internet stock's price increasing that day), or arbitraging (a hedge fund buying cheap call options and selling more expensive "synthetic" calls).

\section{THE NATURE OF THE FIRM AND FIDUCIARY DUTY}

Although derivatives have influenced corporate law in many ways, perhaps the most basic change relates to the nature of the firm and fiduciary duty. Many corporate law texts begin with an introduction to the relationship between risk and return, the attributes of debt and equity, and the effects of leverage. ${ }^{36}$ Inevitably, this discussion involves an overview of the nature of the firm and one or more "stories" illustrating the relationships of the various participants. Who should owe a duty to whom? Why? Where are the potential conflicts? Such an introduction also provides background for later discussion of the legal rules governing participants in the firm.

Derivatives have changed this introduction in several ways. Most fundamentally, option theory has changed how the participants in a firm (e.g., equity and debt) may be conceptualized. In addition, firms can use derivatives to alter the characteristics of instruments held by participants until traditional line-drawing between those participants becomes virtually impossible.

\section{A. THE SIMPLE STORY: THE OPTIONALITY OF EQUTTY}

Suppose Darcy and Edward are planning to invest in a firm. They will need to allocate control, liability, ownership, and management, among other variables. One possible allocation is for Darcy to be the "debt holder" and Edward to be the "equity holder." In

36 E.g., WILLIAM A. KLEIN \& JOHN C. COFFEe, JR., BUSINESS ORGANIZATION AND FINANCE: LEGAL AND ECONOMIC PRINCIPLES 5-12 (6th ed. 1996); O'KELLEY \& THOMPSON, supra note 18, at 1-12. 
such a situation, who owns the firm? The traditional answer has been that Edward owns the firm, because he owns the residual interest. $^{37}$

Derivatives suggest a more complex analysis. Fisher Black and Myron Scholes first recognized that equity in a firm could be recharacterized using options theory. ${ }^{38}$ It is not too difficult to describe equity and debt as having option-like asymmetric characteristics, and the optionality of equity and debt illuminates important concepts, including limited liability and the conflicts among participants in the firm.

The simple version of this story is of equity as a call option. I will call this the call option perspective. In this version, Edward can be thought of as having the right to purchase the assets of the firm from Darcy for the face amount of the debt (plus interest) until maturity. In other words, Edward has purchased (i.e., is long) and Darcy has sold (i.e., is short) a call option. ${ }^{39}$

As noted in Part II, a long call profits when the value of the underlying asset increases. If the firm's value is greater than the exercise price of the option, Edward will have the right to purchase the assets of the firm from Darcy for an amount below the value of those assets. Thus, Edward will capture all of the firm's value above the interest and principal owed to Darcy. Edward has a leveraged position in the underlying assets, another way of describing the general characteristics of a call option.

This analysis demonstrates an important conflict between equity and debt. Equity, as a call option, will benefit if the firm takes on riskier or more volatile projects; conversely, debt will suffer. As a result, debt will seek to include terms in its contract that restrict equity's ability to appropriate such economic value.

${ }^{37}$ See id. at 6 (discussing, in section entitled "Owners and Creditors," the relationship among debt, liability, and ownership).

38 Fischer Black and Myron Scholes first mentioned the option-like characteristics of an equity position in their 1973 article describing the Black-Scholes option-pricing model. See Black \& Scholes, supra note 3, at 649-50 (likening holding of stocks and bonds to holding equivalent of option on company assets).

99 This call option is a European call option because it can only be exercised by repaying the debt at the maturity date of the debt. However, if the debt were callable, the call option could be thought of as an American call option. The premium can be thought of as the present value of interest payments made over time. 
However, the simple story cannot stop there. Characterizing equity as a call option has analytic consequences. In particular, the notion of equity as a call option is entirely inconsistent with the notion that equity owns the assets of the firm.

In fact, from the call option perspective, if Edward has purchased a call option, he cannot be viewed as owning the underlying assets of the firm. Instead, Darcy owns the firm. She has purchased a full interest in the firm's assets and profits, but she has given up some "upside" by agreeing to sell those assets to Edward in the event they are worth more than the value of Darcy's investment. In turn, Edward has agreed to pay a premium (in the form of periodic interest payments) for the right to purchase the assets of the firm from Darcy. Edward owns a call; Darcy owns the underlying assets and has sold a call.

If Edward does not own the underlying assets, does it make sense to say firm managers should owe fiduciary duties to him, rather than Darcy? Why impose on managers a fiduciary duty owed to a participant in the firm who does not own the underlying assets (equity), but not a duty owed to the actual owner of the firm's assets (debt)? Ownership generally is central to the analysis of the firm and fiduciary duties. The central conflict in corporate law, after all, stems from the separation of ownership ${ }^{40}$ and control.

It is possible to characterize debt and equity as having option-like characteristics, while preserving the idea that equity owns the underlying assets of the firm. This characterization requires a shift in perspective. If Edward owns the underlying assets of the firm, he cannot be thought of as the owner of a call option without raising the above fiduciary duty conundrum. Instead, using option theory, Edward can be thought of as both the owner of the assets and the purchaser of a put option. I will call this the put-option perspective. ${ }^{41}$

40 The analysis using derivatives also shows that traditional notions of ownership no longer may be viable. The question of who owns the firm is not easy to answer.

${ }_{41}$ The relationship between these two perspectives is known as put-call parity. In simplified terms, the (equity holder) payoffs generated by ownership of a call option are the same as those generated by ownership of the underlying plus a put option. Similarly, the (debt holder) payoffs generated by ownership of the underlying plus a short call option are the same as those generated by a short put option. 
From this perspective, Edward owns the firm. He owns all of its shares, and he has a full interest in the firm's assets and profits. He has limited liability because Darcy has agreed to suffer all losses beyond the value of Edward's investment (in exchange for Edward's agreement to make periodic interest payments to Darcy). Edward can be thought of as purchasing an insurance policy from Darcy to limit his losses. The insurance policy is a put option: Edward has purchased the right to sell the firm to Darcy at a specified price (zero value of Edward's equity) until Darcy's debt matures. The cost of this put option (its "premium") is simply the present value of the interest payments made to Darcy over time. ${ }^{42}$

Darcy, as the seller of a put option, profits when the value of the underlying asset does not decline. If the firm's value is greater than the face value of the debt, Darcy will make money from her interest payments. However, if the value of the firm falls below the face value of the debt, Darcy will suffer all of the losses beyond that point.

The fact that the simple story has two very different perspectives enriches our understanding of the differences between equity and debt. These perspectives help to illuminate introductory concepts related to the allocation of risk, return, and control between equity and debt. United States corporate law generally assigns control to equity; debt then bargains for specific contractual provisions to protect its interests. Similarly, under normal circumstances, managers owe duties to shareholders but not to bondholders. The put option and call option perspectives demonstrate that the legal rule could be the opposite: corporate law could assign control to debt and force equity to bargain for contractual protection. ${ }^{43}$

The options perspectives thus allow for greater depth of discussion about why control would be assigned to equity. Why, based on

12 This put option is not unlike other put options traded on exchanges. If the owner of a share of stock wishes to insure temporarily against losses beyond a certain amount, that owner may create limited liability through the purchase of a put option.

13 In fact, the roles of equity and debt are reversed in the vicinity of bankruptcy. See, e.g., Geyer v. Ingersoll Publications Co., $621 \mathrm{~A} .2 \mathrm{~d} 784$ (Del. Ch. 1992) (holding that "fiduciary duties to creditors arise when one is able to establish fact of insolvency"); Credit Lyonnais Bank Nederland, N.V. v. Pathe Communications Corp., No. Civ. A. 12150, 1991 WL 277613 (Del. Ch. Dec. 30, 1991) (extending fiduciary duties of managers to creditors when corporation becomes insolvent or approaches insolvency). 
these perspectives, should management necessarily owe a duty to equity over debt? Is there something about a long call option position (when compared to ownership of the underlying assets plus a short call position) or a long put position plus ownership of the underlying assets (when compared to a short put position) that generates a special duty? Both participants have asymmetric payoffs. Both participants hold contingent claims and would need to specify a variety of contingencies in any contract with management or between each other in order to avoid expropriation.

One answer to these questions is that the initial conception of ownership by equity simply fits our intuition better than the initial conception of ownership by debt. Not all firms have debt, and institutional lenders such as banks play a less dominant role in the United States than elsewhere. Another answer is that law needed a singular starting point, either equity or debt. Then, given a particular starting point (equity), the development and reliance on equity-based legal rules made it too costly to switch to a regime in which managers would owe duties to debt, not equity. Still another answer (and the one generally offered by scholars) is that it is easier and less costly to specify contractual provisions for debt, which in most cases will be paid a fixed amount and will default only infrequently, than it is to specify contractual provisions for equity, which in most cases will be paid a variable amount based on the performance of the firm. On the other hand, the assumed relative simplicity of debt is belied by the length and complexity of modern debt contracts.

\section{B. THREE MORE COMPLEX STORIES}

Even if the above questions can be answered, they are merely the beginning. There are other versions of the basic story, in which options illuminate the arbitrariness of assigning control and the benefit of fiduciary duties to equity holders.

First, consider two firms with the same assets but very different capital structures. One firm has debt and equity; the other has equity and call options, or warrants. Assigning control to equity holders in both firms leads to perverse results. 
Specifically, suppose Firm A has $\$ 1,000$ of one-year debt with an interest rate of ten percent and $\$ 100$ of equity. Firm $B$ has $\$ 1,000$ of equity and $\$ 100$ of warrants with an exercise price of $\$ 1,100$ and an expiration date in one year. Both firms have a market capitalization of $\$ 1,100$, the same assets, and the same set of future projects.

Does it make sense to talk about fiduciary duties owed to shareholders in this context? Firm B warrantholders are in precisely the same economic position as Firm A shareholders; why are they not owed the same duties? Put another way, if fiduciary duties run to shareholders of Firm A, but not to warrantholders of Firm B, such duties will lead managers of the firms to behave differently, despite the firms' economic equivalence.

Suppose each firm faces two choices. The Risky Strategy pays $\$ 10,000$ with a ten percent probability and nothing with a ninety percent probability. The Conservative Strategy pays $\$ 1,500$. The firm, and society, are better off if each firm selects the Conservative Strategy. Yet if management's duty is to maximize shareholder value, managers will choose different projects for the firms. Assuming risk neutrality, management of Firm A will choose the Risky Strategy, with an expected value to equity of $\$ 890,{ }^{44}$ over the Conservative Strategy, with an expected value of $\$ 400 .^{45}$ In contrast, management of Firm B will choose the Conservative Strategy, with an expected value to equity of $\$ 1,100$ (the maximum), over the Risky Strategy, with an expected value of $\$ 110 .^{46}$

Alternatively, a maximize-bondholder-value rule would lead Firm A to choose the Conservative Strategy, but would provide no guidance at all for management of Firm B, a no-debt firm. A maximize-warrantholder-value rule would lead Firm $B$ to choose the Risky Strategy, but would provide no guidance at all for management of Firm A, a firm without warrants. As in the above example, there is no good reason for treating economically equivalent participants in firms differently. Moreover, to the extent such firms are treated differently, the differential treatment generates

\footnotetext{
$14 \$ 890=((\$ 10,000-\$ 1,100) \times 10 \%)+(\$ 0 \times 90 \%)$.

$45 \$ 400=\$ 1,5010-\$ 1,100$.

$46 \$ 110=(\$ 1,100 \times \$ 10 \%)+(\$ 0 \times 90 \%)$.
} 
incentives for strategic behavior by managers and additional secondorder inefficiencies.

Second, forward contracts also generate some difficulties for theories of the nature of the firm by shifting the roles of the firm's participants. Suppose a firm has one shareholder, Bill Gates, and that the value of the firm is $\$ 1,000$. Warren Buffett agrees today to purchase all of Gates's shares one year from today at a price of $\$ 1,100$.

To whom should management owe a duty? The shareholder (Gates) has been transformed economically into a debtholder. To see this, consider the performance of Gates's investment. As long as the firm has a value of at least $\$ 1,100$, Gates will receive $\$ 1,100$ in one year, equivalent to $\$ 1,000$ face amount of debt plus ten percent interest. If the firm is worth less than $\$ 1,100$ in one year, Gates will suffer all of the losses in excess of $\$ 1,100$. Gates will not participate in any upside above $\$ 1,100$. Through this forward contract, Gates the shareholder has become Gates the bondholder. Moreover, Gates's return now depends more on Buffett's fortunes than on those of the firm. ${ }^{47}$ Does it really make sense for management to owe duties to Gates?

In contrast, Buffett has become the real shareholder. He will capture any increases in the value of the firm above $\$ 1,100$, the value of the "debt" owed to Gates. Should management then owe duties to Buffett? What if Buffett had agreed to purchase all of Gates's shares at a price of $\$ 1,500$ ? Or $\$ 500$ ?

This hypothetical does not present an unusual type of transaction. Forward transactions in various types of financial assets are becoming increasingly common. Consider, for example, the equity swap, a very popular transaction among large shareholders. In an equity swap, an existing shareholder agrees to pay out any income or capital gain on her stock in exchange for fixed payments over time. Thus, the equity swap presents the same sorts of questions as a forward sale of stock: why should managers owe a duty to shareholders who engage in such transactions?

47 In fact, Gates is not even a creditor of the firm; instead, he is a creditor of Buffett. 
Third, drawing again from option theory, suppose one shareholder (such as a hedge fund) owns all ${ }^{48}$ of Qualcomm's stock. The shareholder owns the stock as part of an arbitrage strategy, because it believes Qualcomm options are mispriced. The strategy is as follows: for each share of stock owned, the shareholder sells one atthe-money call and buys one at-the-money put. The shareholder then manages all of the positions over time to remain neutral with respect to changes in the price of Qualcomm stock. The shareholder seeks to profit from the mispricing of the options (e.g., the calls are dear and the puts cheap, relative to the price of the stock).

Meanwhile, individual investors have decided they are not interested in owning shares of Qualcomm stock because those shares, even if purchased or sold on full margin, do not provide them with sufficient leverage. Instead, investors who believe Qualcomm's stock price will increase have purchased calls and sold puts. As a result, the true (that is, economic) residual interest in Qualcomm stock is held by individual option purchasers and sellers, while the only Qualcomm shareholder is wholly indifferent to movements in the price of the stock.

In such an example, which is not nearly as far-fetched as it might appear on first blush, ${ }^{49}$ corporate law would assign duties to the wrong parties. Why should management owe duties to the hedge fund shareholder, but not to the individual purchasers and sellers of options? To see the perverse effects of current fiduciary duty law, suppose managers contact the hedge fund and say they are planning to engage in a self-dealing transaction that will make the shares worth only half of their current value. The hedge fund shareholder may approve of this transaction, ${ }^{50}$ because it will not negatively impact its investment. Individual investors in options would lose

to For simplicity, I have assumed this shareholder owns all of the firm's stock. However, the argument still would apply, with a lesser degree of force, to the extent there are large block shareholders engaged in similar strategies.

19 Today, the ownership of corporations is dominated by large institutional investors, while purchasers and sellers of options on particular stocks are disproportionately individual investors.

so The shareholder might approve of the transaction because of a side payment by management or because the shareholder will be able to earn additional profits following the transaction by engaging in the arbitrage trading strategy. 
half of their investment as a result of this self-dealing, and yet have no corporate-law remedy. ${ }^{51}$

These examples demonstrate the challenges derivatives pose to the nature of the firm and fiduciary duties. They are consistent with more general arguments, presented most recently by Professor Thomas Smith, that as the owners of financial assets continue to diversify and enter into new types of financial transactions, it makes little sense to speak of fiduciary duties owed to one particular class of investors. ${ }^{52}$

\section{OPTIONS IN CORE CASES}

Apart from the nature of the firm and fiduciary duty, many cases in the basic corporate law course involve derivatives. For example, insider trading cases prosecuted under Rule 10b-5 are thick with options for a variety of reasons. ${ }^{53}$ The same is true of section $16(\mathrm{~b})$ of the Securities Exchange Act. ${ }^{54}$ The role of options in such cases often is quite obvious. ${ }^{55}$

s1 To find for such individual option holders, a court would need to reformulate fiduciary duty law.

${ }_{52}$ See Thomas A Smith, The Efficient Norm for Corporate Law: A Neotraditional Interpretation of Fiduciary Duty, 98 MICH. L. REV. 214, 221 (1999) (arguing that duty should be owed to firm and enforced by each class of investors).

${ }^{33}$ Options are a more efficient means of capitalizing on inside information and, therefore, are likely to continue to dominate insider trading. The Securities and Exchange Commission has shown an interest in prosecuting cases involving options. See, e.g., United States v. O'Hagan, 521 U.S. 642 (1997) (reinstating conviction of lawyer trading both stock and call options). At the same time, more complex financial derivatives, including equity swaps, may be used to skirt the articulated boundaries of insider trading jurisprudence.

${ }_{54}$ See, e.g., Ownership Reports and Trading by Officers, Directors and Principal Security Holders, Release Nos. 34-37260; 35-26524; IC-21997, 17 C.F.R. pts. 228; 229; 240; 249, 1996 SEC LEXIS 1369, May 31, 1996 (discussing details of section 16(b) disclosure obligations for derivatives).

${ }_{55}$ For example, in United States $v$. O'Hagan, the defendant traded both shares and options. O'Hagan, 521 U.S. at 647-48. Options were important in that case because they enabled the defendant to make more money than he otherwise could have made with an equivalent investment in stocks, by providing leverage. Insider trading through the purchase of call options is analytically similar to insider trading through the purchase of stocks on leverage, and courts have implicitly recognized this similarity. See, e.g., Deutschman v. Beneficial Corp., 841 F.2d 502 (3d Cir. 1988) (holding that Rule 10b-5 applies to purchases of call options). 
On the other hand, many cases involve derivatives in less obvious ways; $^{56}$ for these cases, simply pointing out the existence of an option may add important insights. In those cases, analytical workvaluing options also may provide an entirely new perspective. In this Part, I consider how option valuation can be used to generate new insights into two important cases: Smith v. Van Gorkom and Meinhard v. Salmon.

\section{A. SMITH V. VAN GORKOM}

First, consider Smith v. Van Gorkom, ${ }^{57}$ a case most law professors teach in the basic course. Van Gorkom is included in most casebooks as a duty of care case, although it can be used as a vehicle to teach a variety of concepts related to markets, the role of the board of directors, and the mechanics of mergers.

There is, however, little mention made in the case or, as far as I am aware, among law professors about the option Trans Union's board of directors granted to Jay A. Pritzker in that case. Justice Horsey's opinion does not stress the importance or role of this option, nor did Trans Union's Board seem to consider it very important. ${ }^{58}$ The option need not and should not be overlooked.

These are the relevant facts: in September 1980, Trans Union CEO Jerome Van Gorkom approached Pritzker to suggest Pritzker might be interested in buying Trans Union. ${ }^{59}$ Pritzker, being a savvy investor thoroughly grounded in the reality of merger negotiations, immediately requested an option to purchase 1.75 million treasury shares of Trans Union "at market." option would have been important to Pritzker for two reasons. First, it was compensation for expenses Pritzker would undertake in considering and negotiating the merger. Second, it was an

${ }_{56}$ For example, agents with authority to act in a number of different ways can be said to own options. The appraisal remedy is an option of sorts that assists shareholders in monitoring managers. The same is true of the demand requirement, the use of a special litigation committee, and rights held by shareholders and managers.

s7 488 A.2d 858 (Del. 1985).

58 See id. at 877 ("No questions were raised either as to the tax implications of a cash-out merger or how the price for the one million share option granted Pritzker was calculated.").

s9 $I d$. at 866.

60 The shares subject to purchase were held by Trans Union. Id. at 867 . 
insurance policy against Trans Union's negotiating a deal with another buyer. In such an event, Pritzker ultimately might not purchase Trans Union, but, at minimum, he would profit from the appreciated options position. ${ }^{61}$

In response to Pritzker's request, the Trans Union board negotiated Pritzker down from an option to purchase 1.75 million shares (approximately thirteen percent of shares outstanding) ${ }^{62}$ to an option to purchase one million shares (approximately $7.5 \%$ ). ${ }^{63}$ On September 20, 1980, a Saturday, the board approved the merger, including the grant of this option to Pritzker. ${ }^{64}$ The option was to expire 134 days later, on February $1,1981 .^{65}$ The exercise price of the option was set at $\$ 38$ per share, $\$ 0.75$ above the market value of Trans Union stock as of the close of trading on Friday, September $19 .^{66}$

Pritzker did not hold the option until its exercise date. Instead, on October 9, 1980, nineteen days after Pritzker received the option, he exercised it, purchasing one million shares of Trans Union treasury stock for $\$ 38$ per share, a total cost of $\$ 38$ million. ${ }^{67}$ The shareholders approved the merger ${ }^{68}$ in February 1981 at a price of

61 In this respect, the option was a precursor to the modern practice of awarding break-up or termination fees.

${ }_{62}$ There were 13,357,758 shares of Trans Union outstanding at the time. Id. at 864 n.3.

${ }_{63} I d$. at 867 . It is unclear how the board arrived at its proposed option on one million shares as an appropriate grant.

6t Id. at 869 .

65 If Trans Union had not received other favorable offers by this date, the shareholders were to meet to vote on the Pritzker offer. Id. at 870 . Ultimately, the shareholders approved the merger with Pritzker, and the merger became effective on February 10, 1981. Id.

${ }_{66}$ Id. at 867 . In other words, the options were out-of-the-money when granted. Pritzker may have viewed the option as being close to at-the-money because if he had tried to purchase one million shares of stock in the open market (as opposed to the treasury shares he had the right to purchase through the option), he likely would have driven up the price of the stock. In any event, it is clear that the bulk of the value of the option when granted was its time value (i.e., the chance that the stock would be worth more than $\$ 38$ on February 1, 1981), not its in-the-money value.

67 Id. at 870. On October 9, 1980, the day Pritzker exercised his option, Trans Union stock closed at a price of $\$ 53$ 1/8. WALL ST.J., Oct. 10, 1980, at 45. On this same day, Trans Union announced that Pritzker had secured financing for the deal. Van Gorkom, 488 A.2d at 870 . Interestingly, the stock traded at prices above $\$ 55$ on various days between October 10 and February 1981 . See Figure 2 infra. Traders apparently anticipated that the bidding for Trans Union stock would result in a merger at a higher price; this view proved incorrect.

${ }_{68}$ Only $7.25 \%$ of the shareholders voted against the merger; approximately seventy percent voted for it. Van Gorkom, 488 A.2d at 870 . 
$\$ 55$ per share. Pritzker's one million shares had appreciated by $\$ 17$ million, nearly fifty percent.

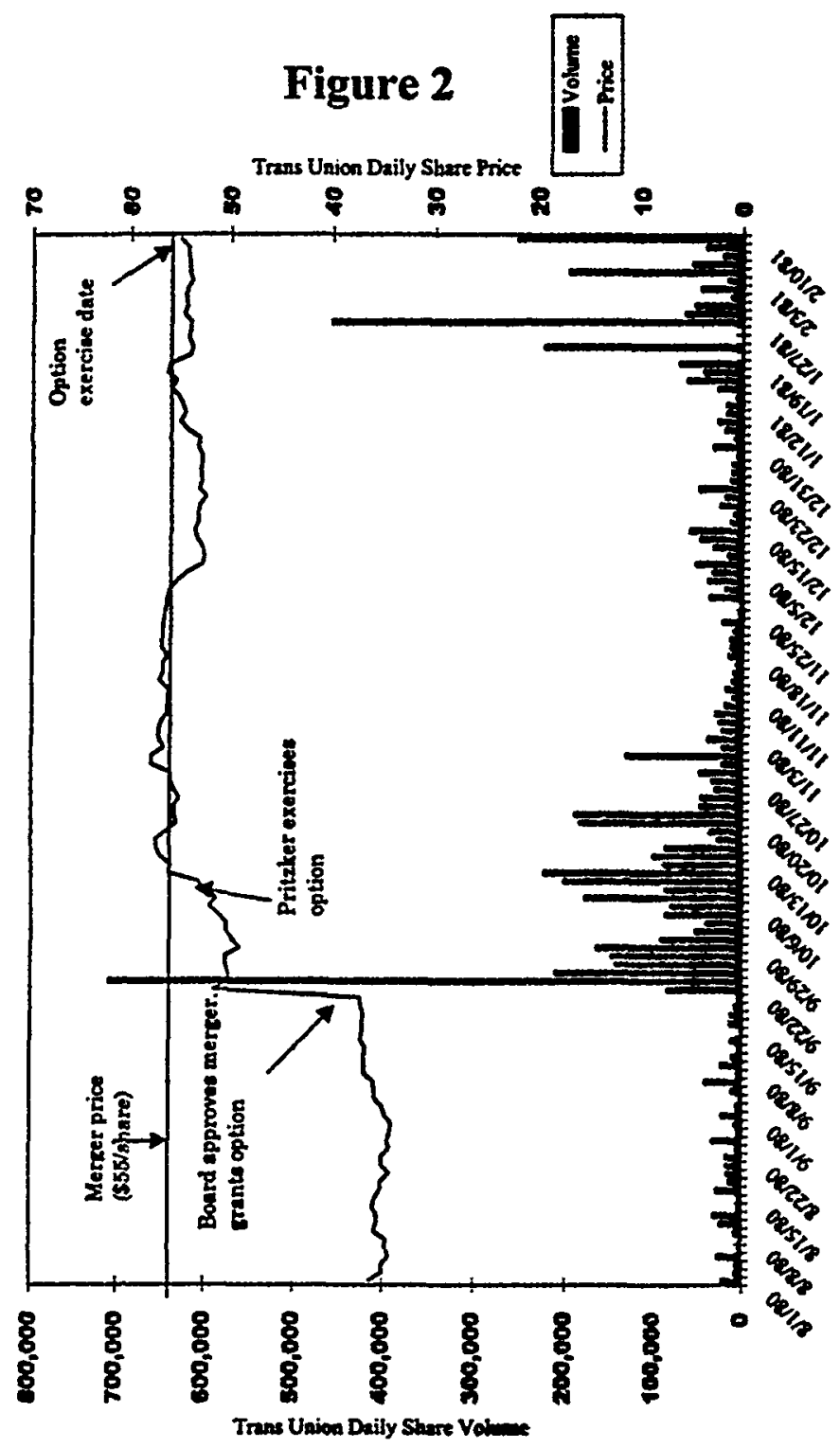


Trans Union's stock price history during this time is telling. Consider Figure 2.

Trans Union stock's price increased from the $\$ 38$ range to the $\$ 50$ range immediately following the board's approval of the merger agreement on September 20, 1980. News of the board's approval obviously was reflected in the market's price, either because the board disseminated the news or because there was insider trading. Then, for several weeks, the stock actually traded above the $\$ 55$ merger price. Apparently, traders must have been anticipating an offer for Trans Union stock with a price higher than $\$ 55$. Interestingly, Pritzker's exercise of the option on October 9 may have driven up the stock price. Trans Union closed at $\$ 531 / 8$ on October 9 and at $\$ 56$ on October 10.

The Delaware Supreme Court ultimately ruled that the Board's decision to approve the merger was not the product of an informed business judgment, and remanded the case on damages. The case later was settled for $\$ 23$ million, with $\$ 10$ million paid by director insurance and $\$ 11$ million paid by Pritzker. ${ }^{69}$

Given the above facts, how can option valuation contribute to an understanding of the case? First, it is important to note that Pritzker's option was quite valuable when granted. Its value can be calculated with some precision using the Black-Scholes option pricing model. Only a handful of data points are required, and it is not necessary to understand the intricacies of the model in order to intuit and use its results.

Some of the data required are given in the case; the other data are available elsewhere. The six required variables are: the stock price at the time the option was granted, the exercise price of the option, the time remaining before expiration, the risk-free interest rate, ${ }^{70}$ the stock's dividend yield,${ }^{71}$ and the stock's volatility. ${ }^{72}$ The value of a call option increases as the stock price increases, the

\% William A. KLEIN \& J. MARK RAMSEYER, CASEs AND Materials [ON] Business ASSOCIATIONS: AGENCY, PARTNERSHIP, AND CORPORATIONS 317 (1997).

${ }^{70}$ The risk-free interest rate needed is that of an instrument with the same maturity as the option.

"11 The dividend yield is simply the annual dividend divided by the stock price.

72 Volatility in the Black-Scholes model is expressed as the standard deviation of the continuously compounded annual returns on the stock. There are various methodologies for estimating volatility from historical data. E.g., HULL, supra note 15, at 88-90. 
exercise price decreases, the risk-free interest rate increases, the dividend yield decreases, or the volatility increases. ${ }^{73}$

First, the stock price at the relevant time is given in the opinion as $\$ 37.25 .^{74}$ Second, the exercise price of the option also is given, $\$ 38 .{ }^{75}$ Third, the time remaining before expiration is 134 days, the number of days from September 20, 1980, until February 1, 1981. Fourth, the risk-free interest rate in effect until the date of maturity of the option can be estimated, based on available data for the yields on comparable maturity United States treasury bills, to be 10.17 percent. ${ }^{76}$ Fifth, Trans Union paid an annual dividend of $\$ 2.36$ per share during $1980 ;{ }^{77}$ therefore, the dividend yield was approximately $6.3 \%$.

The remaining variable, volatility, is more difficult to estimate. The most accurate method of estimating volatility would be to calculate the volatility implied by the prices of Trans Union options being traded in September 1980; however, there were no such options traded at the time. The next most accurate method is to calculate volatility using historical prices of Trans Union stock. The court provides some data about the stock price history. ${ }^{78}$ An accurate estimate, however, requires more frequent and recent data. I estimated volatility based on Trans Union's closing stock price values for the seventy-five business days prior to and including September 20 to be approximately $25.4 \% .^{79}$

73 The effects of the time remaining before expiration are ambiguous.

74 Smith v. Van Gorkom, 488 A.2d 858, 867 (Del. 1982) (stating that "the price was set at $\$ 38-75$ cents above the per share price at the close of the market on September $19^{\prime \prime}$ ).

75 Id.

76 On September 19, 1980, the yield on 91-day T-bills was 10.03 percent, and the yield on 182-day T-bills was 10.33. Interpolating, $10.03+(134-91) /(182-91) \times(10.33-10.03)=$ 10.17. Historical data for U.S. Treasury bills is available at <http://www.enth.com/> (visited Oct. 12, 1999).

77 WALL ST. J., Jan. 25, 1980, at 33.

78 From 1975 through 1979, Trans Union's stock had traded within a range of a high of $\$ 391 / 2$ and a low of $\$ 241 / 4$. Its high and low range for 1980 through September 19 (the last trading day before announcement of the merger) was \$38 1/4-\$29 1/2. Van Gorkom, 488 A.2d at 866 .

${ }_{79}$ This calculation is based on standard methodology for calculating volatility based on historical price information. HULL, supre note 15 , at 88.90. Longer or shorter date ranges could be used, although the resulting volatility measure would not differ substantially. The data are depicted in Figure 2, supra. 
Given these data, the Black-Scholes estimate of the value of Pritzker's option on September 20 is approximately $\$ 2.49$ million. ${ }^{80}$ Table 1 summarizes these results.

\section{Table 1}

Stock Price
Exercise Price
Days to Expiration
Risk-free rate
Dividend Yield
Volatility

Option Value

\author{
$\$ 37.25$ \\ 38.00 \\ 134 \\ $10.17 \%$ \\ $6.3 \%$ \\ $29.3 \%$
}

At least three important new insights arise from this information. First, the grant of one million options to Pritzker on September 20,1980 , was extremely valuable ( $\$ 2.49$ million). Moreover, this value does not include several million dollars of value associated with the increase in the price of the stock as a result of the board's approval of the merger agreement. In fact, the price of Trans Union stock rocketed to $\$ 51.50$ the next day of trading, ${ }^{81}$ and the option would have been much more valuable then. ${ }^{82}$ Because this increase was virtually certain to occur once the merger agreement was disclosed, the option arguably was worth much more than the conservative estimate of $\$ 2.49$ million.

Suppose that instead of granting Pritzker an option, the board had given him a suitcase filled with several million dollars of cash. One can imagine that the board would have considered a grant of such size with greater deliberation. It is possible that the board properly understood the value of the option intuitively, ${ }^{83}$ based on

- I calculated this value using a standard Black-Scholes computer model.

s1 WALL ST. J., Sept. 23, 1980, at 51; see also Figure 2, supra.

82 In fact, even without adjusting for any change in the volatility of the stock the value of the option on Monday, September 22, would have been approximately $\$ 13.8$ million, based on a stock price of $\$ 51.50$ and a time to expiration of 132 days.

it also is possible that someone calculated the value of the option at the time it was granted, but nevertheless determined that it was worth exchanging such value for Pritzker's agreement to merger. However, there is no evidence of such a calculation. 
the directors' experience with the stock's performance over time. In any event, a simple option valuation would have assisted the board's deliberation. Moreover, if the court had been presented with such a valuation, it likely would have included this value as support for its conclusion that the directors violated their duty of care.

Second, the board's efforts to negotiate the grant of the option down to one million from 1.75 million shares saved Trans Union a considerable sum of money, conservatively estimated at $\$ 1.87$ million (option on 750,000 shares at $\$ 2.49$ ). ${ }^{84}$ Including the informational value of the merger agreement, this savings was over $\$ 10$ million. ${ }^{85}$ Again, the court neither stressed the importance or value of this negotiation, nor is it obvious that the board was aware of its magnitude.

Assuming the board understood the relative values of the options, it may have concluded that a substantial grant was necessary to persuade Pritzker to consider the merger agreement. If so, the board's business judgment would seem to have been better informed than the court's findings indicated. On the other hand, if the move from 1.75 million to one million was simply an arbitrary attempt to "round down" Pritzker's initial offer (which may have been based on the assumption that the board would feel the need to negotiate the offer downward), then the board's grant of even a one million share option would not have been well-considered. In any event, the size of the numbers is staggering, and the court did not address any of these issues.

Third, and perhaps more interesting, Pritzker gave up enormous time value when he exercised the option early and purchased one million shares on October 9, 1980. To see the time value Pritzker gave up, consider his alternatives on October 9. Instead of buying one million shares of Trans Union for $\$ 38$ million, Pritzker could have sold a mirror option (in effect, sold a call) on one million shares to another option purchaser (such as an investment bank) on the

8 A grant of 1.75 million options would have been worth approximately $\$ 4.36$ million on September 20 based on the pricing methodology described above (approximately $\$ 2.49$ per share).

${ }_{80}$ As described supra note 82, the option would have been worth approximately $\$ 13.80$ per share on September 22. Therefore, a grant of 1.75 million options would have been worth approximately $\$ 24.15$ million. 
same date. He would have received approximately $\$ 17.3$ million for such a sale. ${ }^{86}$ Then, he could have waited until the expiration date of the option to consider how many shares of Trans Union he wanted to own at that point. Even if the shareholders ultimately had rejected the merger agreement, Pritzker could have exercised his option, delivering those shares to the bank to satisfy his short mirror position, or he could have purchased additional shares.

Pritzker was a sophisticated financier; why would he have chosen to give up this time value by exercising early? A simple answer is that Pritzker made a mistake. This answer, however, ignores several critical factors related to the market for Trans Union stock.

A more likely answer is that Pritzker was taking advantage of the fact that Trans Union stock already was trading close to the merger price of $\$ 55$ per share at the time. As noted above, the value of the option on September 22 was approximately $\$ 13.8$ million. On October 9, just nineteen days after the option was granted, it was worth approximately $\$ 17.3$ million. Pritzker probably did not anticipate the option appreciating any more, given that the difference between the $\$ 55$ per share merger price and the $\$ 38$ exercise price was $\$ 17$ million.

However, the above explanation still does not explain why Pritzker would leave the option's time value on the table, even if it was small relative to his overall profit. Another possible explanation for Pritzker's early exercise is that he was concerned about how his ultimate purchase of shares would affect the market price of Trans Union stock. Because Pritzker had the option to purchase treasury stock, this purchase would not necessarily affect the public market price.

Before September 1980, the average daily trading volume in Trans Union stock was in the tens of thousands of shares. A purchase of one million shares, even staggered over several days, would have been extraordinary. Again, consider Figure 2. On Monday, September 22, 1980, the day after the grant of the option, there were 84,400 shares traded. The next day, Tuesday, volume

86 Again, this calculation is based on the pricing methodology above, with 115 days to expiration and a stock price of 55 1/8. WALL ST. J., Oct. 10, 1980, at 45. 
exploded, with 708,200 shares traded. ${ }^{87}$ Average volumes remained high during the following weeks, but only in the 100,000 to 200,000 share range. No other single day had volume above 250,000 shares.

Still, even if Pritzker had been concerned about a large purchase moving the market (and potentially making the merger more difficult or expensive), a similar problem would have arisen later if Pritzker had decided he wanted to sell the one million shares (perhaps because the shareholders rejected the merger). There is no reason to think selling one million shares of stock would depress the price any less than purchasing one million shares of stock would increase it. Pritzker may have been concerned only about the latter cost (from purchasing) because he did not assign a high probability to his selling the stock later. He seems to have assumed either that shareholders would approve the merger or some other bidder would offer more than $\$ 55$ for Trans Union stock. In either case, he would not be selling stock on the open market.

In sum, the options grant in Van Gorkom can be seen as adding three new insights: (1) the board gave Pritzker at least $\$ 2.49$ million of option value (one million shares at $\$ 2.49$ apiece) and probably much more, (2) Pritzker requested, and the board rejected, a grant with option value of at least $\$ 4.36$ million (1.75 million shares at $\$ 2.49$ apiece) and probably much more, and (3) after the option was granted, Pritzker immediately relinquished its time value by exercising early, presumably in exchange for the substantial benefits associated with a pre-expiration, non-public, off-market purchase of one million shares of stock.

Today, one would expect both the prospective purchaser of a company and its board to attempt to evaluate such an option using the above methodology. In such instances, lawyers advising participants in mergers need to understand the basics of option

87 The volume increases, as well as the increase in the stock price, are interesting in themselves. They show that news of the merger agreement was reflected in stock prices very quickly. They also show a tremendous increase in average daily volume following the merger agreement. 
valuation. ${ }^{88}$ Trans Union's directors, and its counsel, might have fared better if they had.

\section{B. MEINHARD V. SALMON}

Similar analyses are possible for many cases in the basic corporate law course, and this Essay is intended more as a brief to persuade others to begin evaluating such options than as an encyclopedia of option valuation in corporate law cases. Some cases will work better than others, and some will generate ambiguous conclusions. Not all cases include options that are as easy to calculate as the one in Van Gorkom, although option theory may yield interesting conclusions even if precise calculations are not possible.

As an example of a more difficult and less obvious option valuation case, consider Meinhard $v$. Salmon. ${ }^{89}$ The relevant facts: ${ }^{90}$ Meinhard and Salmon were "coadventurers" in a twenty-year lease of the Hotel Bristol property in New York City. Salmon negotiated the lease but did not have the $\$ 200,000$ required to make additions and alterations to the property. Meinhard agreed to pay half of these reconstruction costs, or $\$ 100,000$. In return, Meinhard received the right to forty percent of net profits for the first five years, and fifty percent of net profits for the next fifteen years. Near the end of the lease, Salmon learned of a new opportunity related to the property and took the opportunity for himself, without offering it to Meinhard. Meinhard learned he had been slighted and sued. Judge Cardozo hurled a "punctilio"1 at Salmon and found him liable.

How is option theory relevant to this 1928 case? Meinhard can be thought of as purchasing a twenty-year call option on future projects with Salmon. Thus, Meinhard's investment can be split

88 In addition, it is worth noting that many students later will encounter option valuation in practice, as they review such valuations in disclosure documents or in defending or cross-examining expert witnesses.

164 N.E. 545 (1928).

90 Id. at 545-46.

91 See id. at 546 ("A trustee is held to something stricter than the morals of the market place. Not honesty alone, but the punctilio of an honor the most sensitive, is then the standard of behavior."). 
into two parts: (1) the right to receive a percentage of net profits over time, and (2) an option to invest in future projects related to the property. Judge Cardozo's holding can be interpreted as saying that this composition of Meinhard's investment is the correct one. In contrast, Judge Andrews in dissent ${ }^{92}$ can be interpreted as saying that Meinhard's investment included only part (1), not part (2).

To determine which interpretation is correct, we can attempt to value the option in part (2). This valuation requires a sort of hypothetical bargain analysis, looking at the negotiations of the parties ex ante. Put simply, what would Meinhard have paid for the option to invest in future projects? If that value is roughly approximated by the terms of the agreement, then it seems reasonable to say, as Cardozo does, that Meinhard had the right to invest in future projects related to the property. On the other hand, if that option is so valuable that Meinhard cannot reasonably be said to have purchased it at the outset, then Judge Andrews's dissent seems more reasonable.

The option to invest in future projects related to the land can be evaluated using the Black-Scholes model. Unfortunately, in contrast to the data in Van Gorkom the six variables needed to price this option are not easily specified. For example, there is no clear price of any underlying asset, nor any obvious exercise price. It is difficult to estimate what an equivalent measure of dividends might be. It is virtually impossible to estimate volatility.

The only parameter in the model (other than the risk-free rate) that can be specified with any degree of accuracy is the time to maturity: twenty years. Yet this may be enough.

A twenty-year call option is extremely valuable, regardless of the values of the other variables. Assuming the option was at-themoney, a reascinable valuation could be in the range of fifty to one hundred percent of the value of the underlying asset. Such an option would be worth between $\$ 100,000$ and $\$ 200,000$. Depending on the range of projects encompassed by the "assets" underlying the option, the value might be significantly higher. Because Meinhard invested only $\$ 100,000$ total, this high valuation suggests a conclusion that Meinhard did not purchase the option on future

92 Id. at 550-52. 
projects, and therefore supports Judge Andrews's dissent. We not only would expect Meinhard and Salmon to include in their contract an option term of such obviously high present value; but we also would expect Meinhard to pay for it.

On the other hand, the nature of partnerships and the role of partnership law may be to account implicitly for such options to minimize transaction costs. An efficient default rule might be that partnership agreements implicitly include certain valuable, yet difficult to value, options granted by parties to each other. For example, if Meinhard had asked Salmon to include future projects related to the land as part of their agreement, and Salmon had insisted on payment of an additional $\$ 100,000$ for such a provision, the parties might have been unable to reach any agreement at all. Alternatively, Meinhard might have required that Salmon pay for some equivalent expensive and difficult-to-specify option. Rather than force the parties to suffer the arduous process of (and costs associated with) specifying and pricing difficult-to-evaluate, longterm options, the law may supply a low-cost default rule. Such an analysis would support Judge Cardozo's view.

The above two cases are not meant to be exhaustive. Rather, they are intended to show that option theory can add value to the basic course even when the optionality appears to be on the fringes of a case (the option in Van Gorkom) or to be virtually impossible to specify (the "option" in Meinhard).

\section{CONCLUSION}

Derivatives can add a range of issues and interpretations to the basic corporate law course. This Essay has suggested a few. The applications of derivatives reach far beyond the mere presence of options in insider trading cases. Hypothetical examples involving derivatives can be added to various parts of the course for all three of the essential uses of derivatives (hedging, speculating, and arbitrage).

Additional questions include the following: do managers owe a duty to hedge (to reduce risk) or not to hedge (because diversified shareholders can reduce risks on their own)? Consider the manag- 
ers of an airline faced with the risks associated with an increase in the price of fuel. What risks are stockholders buying?

Do managers owe a duty to speculate (when it has positive expected value) or not to speculate (when it may generate excessive risk)? How should managers of a bank monitor the riskiness of lower level employees' behavior? What obligation, if any, does the seller of a complex instrument who knows its value have to a buyer who is incapable of valuing it?

Do managers owe a duty to take advantage of arbitrage opportunities? What about opportunities to skirt legal rules when it benefits the firm or otherwise to reduce regulatory costs? What types of disclosure should be required for derivatives, including stock options granted to or held by managers and employees?

As derivatives become more pervasive and the market grows, the numerosity and difficulty of such questions will increase. It will become more important that corporate lawyers and academics understand the basics, and those who do will have a tremendous advantage. History has favored those who heed the momentous scribbles on the blackboard. ${ }^{93}$

93 Indeed, Stanislaw Ulam's quote, supra note 1, reflects surprise, not only at how the equations of theoretical physicists during the early 1900s affected the development of the atomic bomb, but at how the outcome of World War II was determined essentially by which group of political leaders paid attention to these equations. 
